\title{
Environmentally Friendly Rice Farmer Empowerment for Sustainable Food Security in Banten Province
}

\section{Pemberdayaan Petani Padi Sawah Ramah Lingkungan dalam Mewujudkan Ketahanan Pangan Berkelanjutan di Provinsi Banten}

\author{
Asih Mulyaningsih*), Suherna, Gugun Gunawan
}

Department of Agribusiness, Sultan Ageng Tirtayasa University, Serang 42124, Indonesia

${ }^{*}$ E-mail korespondensi: asihmulya@ymail.com

Accepted: 22 October 2020 | Approved: 29 April 2021 | Online Publication: 3 May 2021

\begin{abstract}
Empowerment is a key factor in accentuating the role of farmer communities as the main actors in managing the cultivation of Indonesian staple food, that is, rice. This study was intended to analyze the factors influencing the empowerment of farmers to manage environmentally friendly lowland rice production for sustainable agricultural development in Banten Province. With a descriptive design, this research collected data through a questionnaire survey involving 180 respondents, sampled from a predefined population of rice farmers. It was carried out in three regencies in the province, namely Serang, Pandeglang, and Lebak, for three months from April to June 2019. The data were analyzed using statistical inference, SEM, in LISREL 8.73 (Linear Structural Relationships). The results showed that the empowerment of lowland rice farmers to adopt eco-friendly innovation was determined by individual characteristics (i.e., non-formal and formal educational attainment and cosmopolitanism) and the existence of encouragement to implement the innovation (i.e., support from farmer community, market support, and technological information support). In conclusion, to increase the empowerment of rice farmers in the scheme of sustainable food security, farmers, government, and other relevant parties need to pay attention to the characteristics of innovation users and promote the adoption of eco-friendly practices in lowland rice cultivation.
\end{abstract}

Keywords: Empowerment, environmentally friendly, lowland rice

\section{ABSTRAK}

Pemberdayaan merupakan salah satu faktor kunci dalam mengedepankan peran masyarakat petani sebagai pelaku utama dalam pengelolaan budidaya pangan pokok Indonesia yaitu beras. Penelitian ini bertujuan untuk menganalisis faktor-faktor yang mempengaruhi pemberdayaan petani dalam mengelola produksi padi sawah ramah lingkungan untuk pembangunan pertanian berkelanjutan di Provinsi Banten. Metode penelitian ini adalah deskriptif. Untuk mengumpulkan data penelitian, menggunakan kuesioner yang melibatkan 180 responden yang diambil dari populasi petani padi yang telah ditetapkan. Penelitian dilakukan di tiga kabupaten di Provinsi Banten, yaitu Serang, Pandeglang, dan Lebak. Penelitian dilaksanakan selama tiga bulan dari April hingga Juni 2019. Analisis data menggunakan inferensi statistik, SEM, dalam LISREL 8.73 (Linear Structural Relationships). Hasil penelitian menunjukkan bahwa pemberdayaan petani padi sawah dalam mengadopsi inovasi ramah lingkungan ditentukan oleh karakteristik individu (yaitu pencapaian pendidikan nonformal dan formal serta kosmopolitanisme) dan adanya dorongan untuk melaksanakan inovasi (yaitu dukungan dari masyarakat petani, dukungan pasar, dan dukungan informasi teknologi). Kesimpulannya, untuk meningkatkan pemberdayaan petani padi maka pemerintah, dan pihak yang terkait, perlu memperhatikan karakteristik pengguna inovasi dalam penerapan praktik ramah lingkungan.

Kata kunci: Pemberdayaan, ramah lingkungan, padi sawah

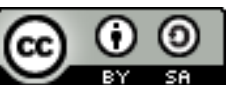




\section{INTRODUCTION}

Farmers are required to be able to make the best and most profitable decisions for their farming. Efforts to make farmers empowered are needed in achieving food security, as mandated by Law no. 16 of 2006 concerning Fisheries and Forestry Agricultural Extension Systems (SP3K). An extension approach suitable for empowering farmers is one that puts farmers first. Various agricultural extension programs that have been carried out over the past two decades have begun to adopt the approach to developing human resources (HR) for farmers (prioritizing farmers), which are expected to empower farmers so that they can make the best and profitable decisions for their farming (better business) in realizing family food security.

Food security is the most strategic issue in a regional development. Attention to its conditions is undoubtedly necessary, given that it is closely related to social security, economic stability, and political balance. FAO explains that food security is a physical and financial state in which people have guaranteed access to staple food at any time. The agricultural sector has a strategic position in a national economic development, but in achieving self-sufficiency in rice, farmers' empowerment is paramount. Moreover, many gender issues have been identified in this sector, particularly those related to access to opportunities, participation in the decision-making process, the control of resources, and the distribution of benefits from development outcomes (Astuti, 2012; Sadono, 2008).

This paper focuses on food security with the sub areas Learning Community and Empowerment. Previous studies emphasize aspects of cultivation techniques, strategies to overcome the negative impacts of conventional agriculture, and the evaluation of technological application in rice cultivation improvement programs (Herawati et al., 2018). From these works, strategies to make better the empowerment of farmers in sustainable agriculture have been formulated, including technical skills to actualize environmentally or eco-friendly innovation in every step of farming practices, starting from land preparation to crop rotation, balanced use of organic and inorganic fertilizers, pest control, harvest, and then post-harvest. Based on these phases, four capacities are deemed the most closely related to environmental aspects, namely the abilities (1) to rotate and utilize new superior seeds, (2) to carry out water management, (3) to use organic and inorganic fertilizers proportionally, and (4) to implement integrated pest control (IPC) using plant-based pesticides or making use of natural enemies.

Since economic interests and environments constantly change, technical skills are required in solving farming problems and improving adaptability. Limited empowerment means farmers are unable to overcome the increasingly fluctuating price of farming input, which is frequently combined with a reduced level of subsidies on fertilizers and rice seeds. Inevitably, farmers apply little to no fertilizers, which is noncompliant with the recommended use. At the same time, they still rely on high concentrations of pesticides for pest control.

Farmers can implement eco-friendly innovation sustainably to the extent of not only their technical skills and knowledge of the environment, but also their ability to plan and evaluate their agricultural business to achieve efficiency. Adaptability, composed of resilience and adaptive empowerment, is persistently low among farmers. Not a few farmers cease to persevere with unfavorable conditions, for example, cultivating crops based merely on common practice or knowledge passed down through generations without making an effort to address, among others, infertile soil, limited water availability, pest outbreak, and low production.

Moreover, farmers have yet to anticipate changes in consumer tastes, such as preferences of organic products with minimal chemical residues. Empowerment building is possible when supported by farmers' ability to establish synergic partnerships, including initiate communication, interact, and work together with other farmers. These efforts are a crucial process in exchanging experiences and ideas and transforming non-formal education and perceptions. Being adept at cooperating with other groups and organizations is believed to be able to overcome problems arising from limited capital and technology, a decrease in product quality, and marketing challenges. This study seeks to analyze factors influencing the empowerment of rice farmers to implement eco-friendly innovation for sustainable agricultural development in Banten Province, Indonesia.

\section{METHODS}

This quantitatively designed study employed a questionnaire survey as the procedure or way to collect

Jurnal Penyuluhan | Vol. 17 (01) 2020 | 103 
data and information from several respondents in three months, April-June 2019. Analytically, surveys allow the generalization of an observed population from its samples (Pirngadi, 2009). Whether the predefined variables exist, correlate, and have any effect was quantitatively determined using statistical tests. The study area was selected purposively to solely include the centers of production in a particular regency, district, village, and farmer community. From this technique, three regencies in Banten Province, Indonesia, were selected, namely Serang, Pandeglang, and Lebak.

The research population consisted of the heads of farm households who were members of farmer communities. It amounted to 180 farmers spreading across the three regencies. The sampling technique comprised two stages, namely deciding the sample size and identifying the number of respondents in each sampled regency. In the first stage, the sample size was calculated according to the principles of the Structural Equation Modeling (SEM) analysis, in which the maximum likelihood estimation requires a minimum of 100-150 samples or five times as large as the indicators used in the model. In this study, there were 32 indicators, and the number of samples was therefore 5 x $32=160$ fulfilled to be 180 . The research sample taken was 180 respondents who were taken from three districts. The selected respondents were farmers who were members of farmer groups. From each district three sub-districts were selected and two villages were selected in each sub-district, then from each village one farmer group was selected. 15 respondents were taken from each farmer group, provided that for each group 3 administrators were taken by census, and 12 other members were randomly selected from the 25 farmers in each farmer group.This sample size met the requirements of SEM testing. In the second stage, the number of respondents in each selected regency was determined, and both data processing and analysis were performed in Linear Structural Relationships (LISREL 8.72) program. The research variables were grouped into two, namely the independent variable (X) and the dependent variable (Y). SEM is a parametric statistical test, and for this reason, the measurement scales of all data were transformed into interval. Scale conversion was performed by assigning the lowest (highest) index to variables with the smallest (largest) scores in each indicator. The general formula of index transformation used in this study is as follows.

$$
\mathrm{TI}=\frac{\text { ScoreAchieved-Minimum Score }}{\text { Maximum Score-Minimum Score }} \times 100
$$

Indicators expectedly have dissimilar lowest or highest scores because each of them consists of several question items. After the scale transformation, the index varies between 0 and 100 . The smallest, 0 , represents the total minimum score, whereas the largest, 100, is the total maximum score of each indicator. The research variables including the variable $\mathrm{X}_{1}$ (the individual characteristics) has five measured variables, namely $\mathrm{X}_{1.1}$ Non-formal education, $\mathrm{X}_{1.2}$ Formal education, $\mathrm{X}_{1.3}$ Cosmopolitanism, $\mathrm{X}_{1.4}$ Land area, and $\mathrm{X}_{1.5}$ Agricultural experience. Variable $\mathrm{X}_{2}$ (availability of agricultural information) has three measured variables, namely $\mathrm{X}_{2.1}$ meaning of information, $\mathrm{X}_{2.2}$ amount of information, and $\mathrm{X}_{2.3}$ quality of information. Variable $\mathrm{X}_{3}$ (farmer personality traits) has four measured variables, namely $\mathrm{X}_{3.1}$ The spirit of hard work, $\mathrm{X}_{3.2}$ Self confidence, $\mathrm{X}_{3.3}$ Courage to risk, and $\mathrm{X}_{3.4}$ Creativity. Variable $\mathrm{X}_{4}$ (the nature of eco-friendly rice farming innovation) has five measured variables, namely $\mathrm{X}_{4.1}$ Relative benefits, $\mathrm{X}_{4.2}$ Complexity, $\mathrm{X}_{4.3}$ Suitability, $\mathrm{X}_{4.4}$ The ease of small-scale application, and $\mathrm{X}_{4.5}$ Result observability. Variable $\mathrm{X}_{5}$ (encouragement to adopt eco-friendly innovation) has five measured variables, namely $\mathrm{X}_{5.1}$ Support from farmer community, $\mathrm{X}_{5.2}$ Support from local leaders, $\mathrm{X}_{5.3}$ Availability of raw materials, $X_{5.4}$ Market support, and $X_{5.5}$ Technological information support. Variable $\mathrm{Y}_{1}$ (farmer's level of empowerment) has four measured variables, namely $\mathrm{Y}_{1.1}$ Technical ability to implement eco-friendly innovations, $\mathrm{Y}_{1.2}$ Ability to overcome problems, $\mathrm{Y}_{1.3}$ Agricultural business planning ability, and $\mathrm{Y}_{1.4}$ Adaptability to the environment. Variable $\mathrm{Y}_{2}$ (food security) has three measured variables, namely $\mathrm{Y}_{2.1}$ Consumption, $\mathrm{Y}_{2.2}$ Food availability, and $\mathrm{Y}_{2.3}$ Food distribution, while variable $\mathrm{Y}_{3}$ (sustainability in applying eco-friendly innovation) consists of three sub-variables, namely $\mathrm{Y}_{3.1}$ Economic sustainability, $\mathrm{Y}_{3.2}$ Social sustainability, and $\mathrm{Y}_{3.3}$ environmental sustainability. The research hypothesis is that the pattern of division of labor, the characteristics of farmers, farmer personality traits, the nature of eco-friendly rice farming innovation, and encouragement to adopt ecofriendly innovation are variables affecting the empowerment of rice farmers. The hypodermic model of farmer empowerment for environmentally friendly lowland rice production to realize food security is depicted in Figure 1. 


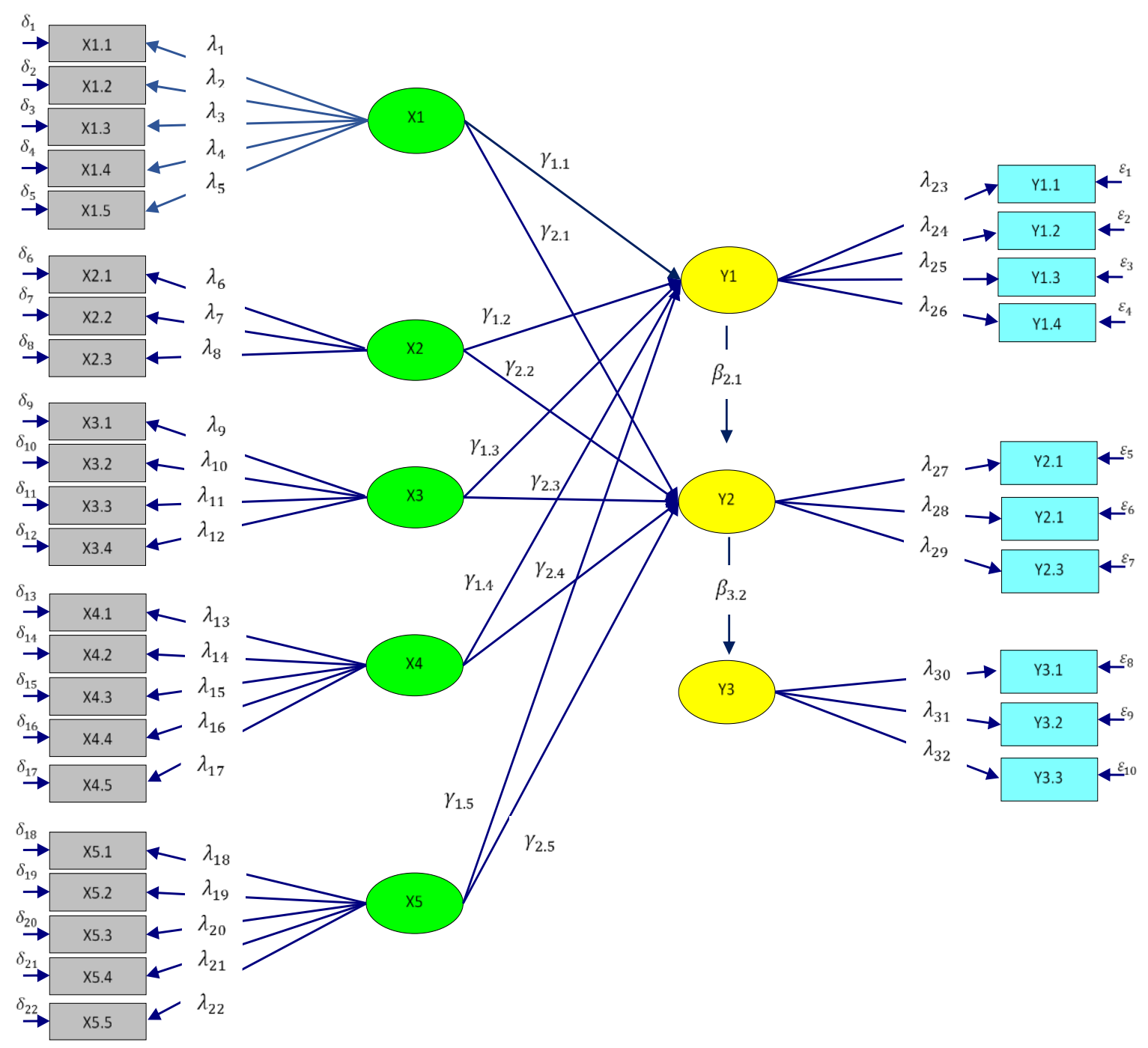

Figure 1. The hypodermic model of farmer empowerment for environmentally friendly lowland rice farming

\section{RESULTS AND DISCUSSION}

\section{Factors Influencing Farmers' Empowerment in Eco-friendly Lowland Rice Farming}

The empowerment of farmers depends on factors that determine the success of eco-friendly lowland rice cultivation in Banten Province, namely farmer's individual characteristics (i.e., non-formal and formal educational attainment and cosmopolitanism) and encouragement to adopt the eco-friendly innovation (i.e., group support, market support, and technological information support). According to (A. Mulyaningsih \& Sumantri, 2019), to empower farmers means to firstly shift the old paradigm that emphasizes technological change to a new one that highlights human resources, or called the "farmer first" approach i.e., changing the farmers instead of the way of farming. Figure 1 shows factors that directly and indirectly play a role in shaping the empowerment of farmers to manage eco-friendly rice farming.

The hypothesis was formulated as follows. "The characteristics of the farmer $\left(\mathrm{X}_{1}\right)$, availability of agricultural information $\left(\mathrm{X}_{2}\right)$, farmer personality traits $\left(\mathrm{X}_{3}\right)$, the nature of eco-friendly rice farming innovation $\left(\mathrm{X}_{4}\right)$, and encouragement to adopt eco-friendly innovation $\left(\mathrm{X}_{5}\right)$ significantly affect the empowerment of farmers to manage eco-friendly lowland rice farming". Mathematically, the structural model equation of these factors was $\mathrm{Y}_{1}=0.32 * \mathrm{X}_{1}+0.10 * \mathrm{X}_{5}$, with $\mathrm{R}^{2}=0.13$, meaning that these four variables simultaneously affect the empowerment of rice farmers by 0.13 . In other terms, the model can explain $13 \%$ of the diversity of the data, while the rest $(87 \%)$ was shaped by unknown variables (not included in the model) and errors. 
Some independent variables, as designed in the hypothesis, exhibited a statistically significant influence on the empowerment of farmers to manage lowland rice farming. These variables were the inherent characteristics of the farmer $\left(\mathrm{X}_{1}\right)$ and encouragement to adopt eco-friendly innovation $\left(\mathrm{X}_{5}\right)$. As for the other variables, i.e., availability of agricultural information $\left(\mathrm{X}_{2}\right)$, farmer personality traits $\left(\mathrm{X}_{3}\right)$, and the nature of eco-friendly rice farming innovation $\left(\mathrm{X}_{4}\right)$, showed no significant effects on the empowerment of farmers to implement eco-friendly lowland rice farming. $\mathrm{X}_{1}$ and $\mathrm{X}_{5}$ had a direct impact, and based on the standardized regression coefficient $(\beta)$, encouragement to adopt eco-friendly innovation had a stronger effect $(\beta=0.38)$ than the individual characteristics of the farmer $(\beta=0.32)$. Accordingly, the hypothesis is accepted for variables $\mathrm{X}_{1}$, and $\mathrm{X}_{5}$, but rejected for variables $\mathrm{X}_{2}, \mathrm{X}_{3}$, and $\mathrm{X}_{4}$.

The structural modeling evaluates coefficients or parameters that reflect a causal relationship or the effect of one latent variable on measured variables. In this study, it examined the significance of the estimated coefficients using three measures, namely (a) t-value of the coefficient of the structural equation, (b) coefficient or parameter values in the structural equations, and (c) the coefficient of determination $\left(\mathrm{R}^{2}\right)$.

The SEM method, as processed in the LISREL program, has provided output values, namely estimated coefficients, $\mathrm{t}$-value for each coefficient, and $\mathrm{R}^{2}$ for each structural equation. With a particular significance level (usually $\alpha=0.05$ ), each coefficient representing a hypothesized causal relationship can be statistically tested for its significance (whether it is significantly different from zero or not). The structural model analysis was performed on the diagram or standardized solution equation in which all coefficients had the same variance and maximum value. Based on SEM analysis in the LISREL program, the assessed parameters of the structural equation model after re-specification are depicted in Figure 2.

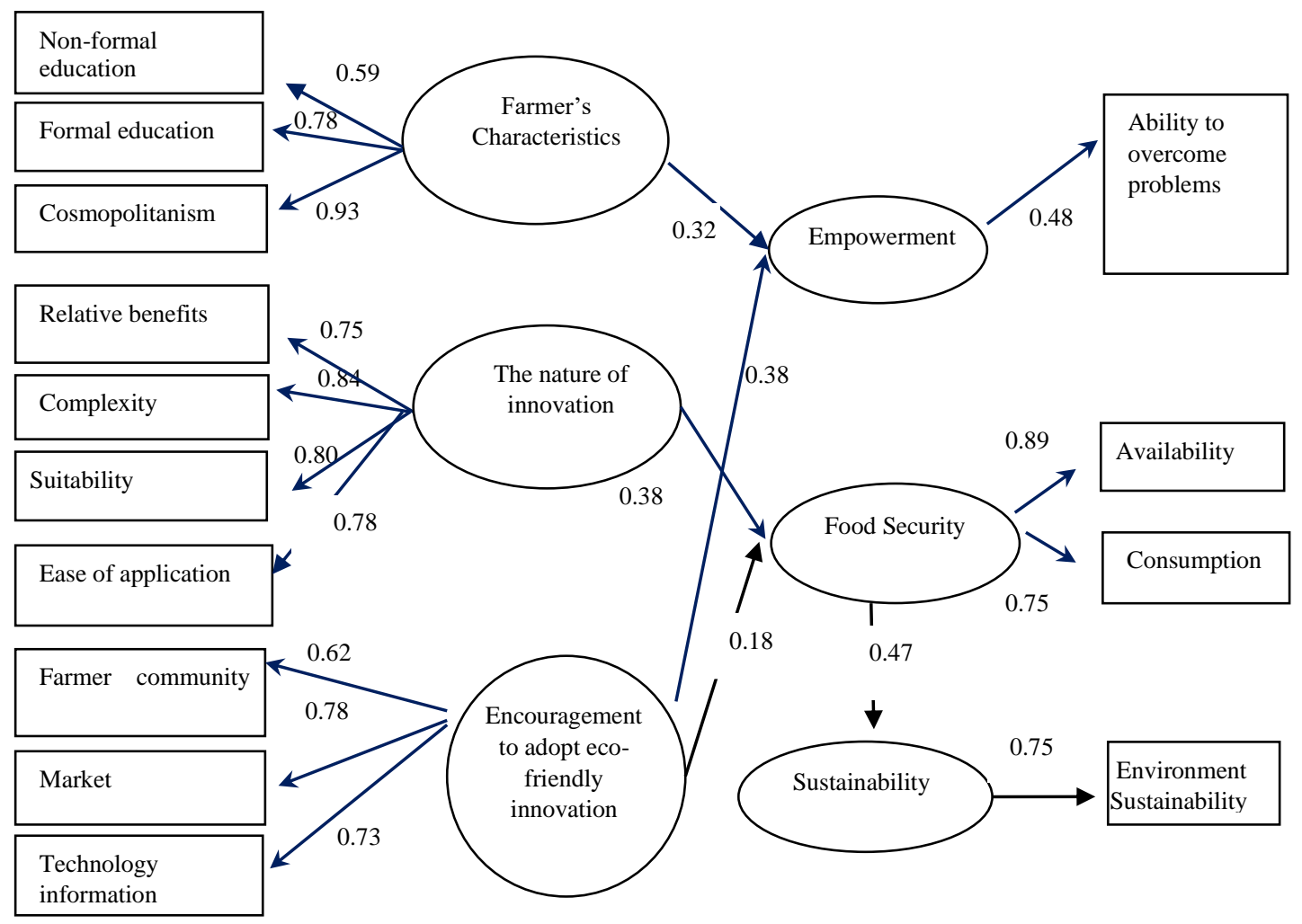

Chi-Square=251.40. $\mathrm{df}=112 . \mathrm{P}$-value=0.00000. $\mathrm{RMSEA}=0.076$

Figure 2. The estimation of the parameters of the structural/hybrid model (standardized), in particular, factors affecting the empowerment of farmers to manage environmentally friendly lowland rice farming 
The test results of several measurement indicators produced a conclusion that the model met the goodness-of-fit criterion. In Root Mean Square Error of Approximation (RMSEA), $0.05 \leq \mathrm{RMSEA} \leq 0.08$ means that the generated model has an acceptable fit. As seen in Table 1, this study also used other goodness-of-fit indices, namely Goodness-of-Fit Index (GFI), Adjusted Goodness-of-Fit Index (AGFI), Comparative Fit Index (CFI), and Normed Fit Index (NFI). In GFI calculation, index approaching 1 indicates that the model corresponds to the reality, as represented by relatively good data. In other words, the proposed measurement of constructs fits the data, confirming that the model can estimate the covariance matrix of the sample data.

Table 1. The goodness-of-fit indices of the model of lowland rice farmer empowerment in 2019

\begin{tabular}{lccc}
\hline \multicolumn{1}{c}{ Goodness-of-Fit } & Cut-off Value & Results & Conclusions \\
\hline RMSEA & $0.05 \leq$ RMSEA $\leq 0.08$ & 0.07 & Excellent Fit \\
GFI & GFI $>0.90$ & 0.88 & Fit \\
AGFI & $0.80 \geq$ AGFI $>0.90$ & 0.83 & Fit \\
CFI & $\geq 0.90$ & 0.94 & Excellent Fit \\
NFI & $\geq 0.90$ & 0.89 & Fit \\
\hline
\end{tabular}

\section{The Effects of Farmers' Characteristics on Empowerment}

Figure 2 shows that the individual characteristics that significantly affect farmers' empowerment are non-formal education $\left(\mathrm{X}_{1.1}\right)$, formal education $\left(\mathrm{X}_{1.2}\right)$, and cosmopolitanism $\left(\mathrm{X}_{1.3)}\right)$. These three measured variables showed a direct influence, with cosmopolitanism exhibiting the most considerable effect (0.93), followed by formal education (0.78) and non-formal education (0.59).

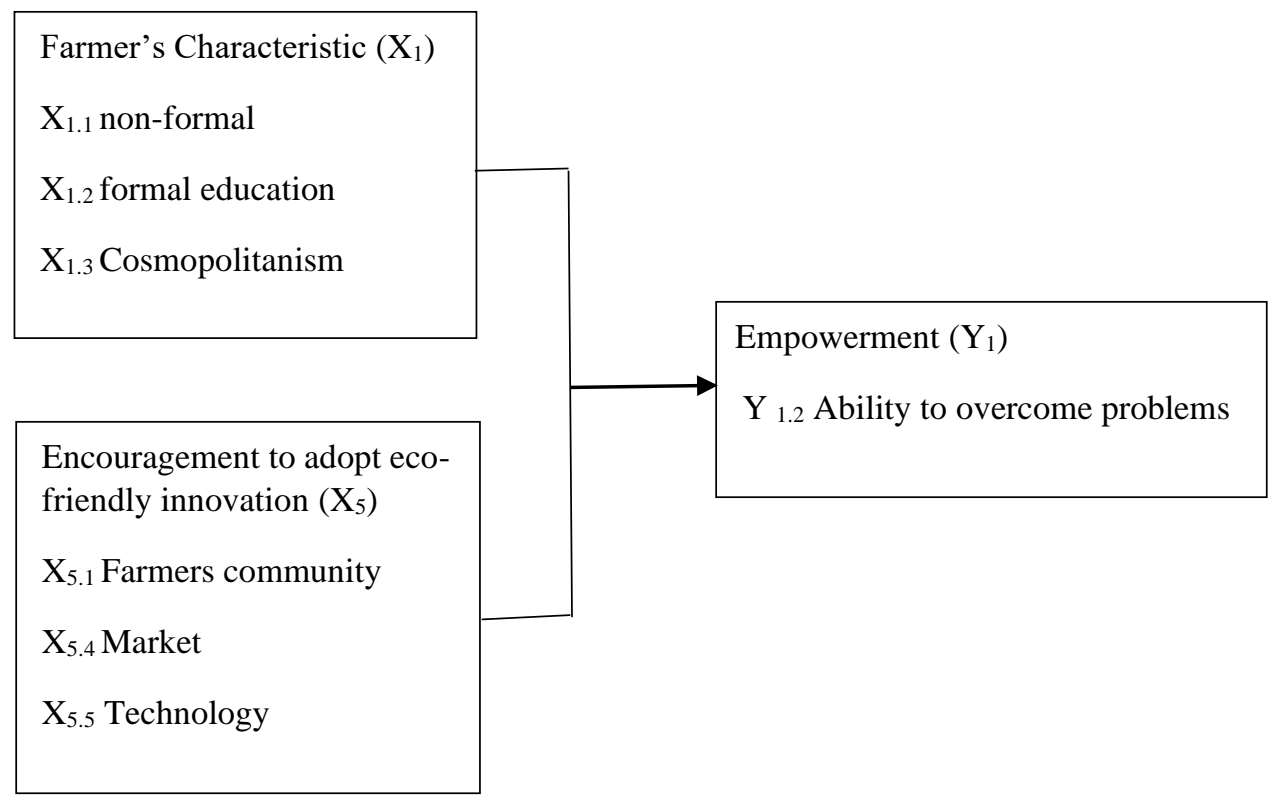

Figure 3. Empowerment Model

From the SEM model produced, there are two pathways of influence towards the empowerment of lowland rice farmers (Figure 3). The two pathways are farmer's characteristics and support for applying the innovation. SEM model of the results of data processing using LISREL 8.72, produced variables that affect the empowerment of environmentally friendly lowland rice farmers (figure 3 ).

\section{Cosmopolitanism}

The measurement model showed that cosmopolitanism played an essential role, with a weight of 0.93 in shaping farmers' characteristics. A cosmopolitan farmer is associated with higher empowerment. However, lowland rice farmers in the study area were rather far from this behavior, as evident from the rare consultation to related institutions and a low number of visits from and to other regions as an attempt to find information on farming. Also, they did not have other activities outside their social 
system because most of their time was spent on completing other works. In general, farmers cared for not only lowland rice fields but also other dry agricultural lands planted with corn, sweet potatoes, vegetables, and other annual crops, such as cocoa, coconut, and clove. Having a cosmopolitan nature, farmers enthusiastically traveled outside their village to obtain information about the means of production used by other farmers, organic products (no chemicals in the production process), and prices. The more information they obtain, the higher their empowerment becomes.

\section{Formal Education}

Formal education was proven as a determinant of farmers' empowerment (weight $=0.78$ ), meaning that higher educational attainment is associated with a more exceptional ability to manage eco-friendly lowland rice farming. Farmers who had formally attended junior high school or equivalent understood the danger of using chemical fertilizers continuously in rice production, including damaged soil and reduced nutrient content. With this knowledge, the farmers in the three selected regencies had been using organic fertilizers.

\section{Non-formal Education}

Non-formal education is defined as a type of education obtained outside of school enrolments. In the agricultural sector, the examples include training, field schools, and internships. A more frequent, active participation in non-formal education is believed to increase the ability of farmers to manage eco-friendly lowland rice farming.

This study found that non-formal education (weight $=0.59$ ) was an observed variable (manifest) of farmers' characteristics that played a significant role in modifying the empowerment to overcome problems. Unfortunately, non-formal education among lowland rice farmers was still lacking. Most of them claimed that they had never attended, for instance, farmer field schools of integrated lowland rice farming management. Although there had been many agricultural extensions, they did not reach all farmers in the study area. Very few of these extensions only invited those who had frequently participated in previous programs, causing other farmers to develop feelings of envy. As a result, farmers with less active participation in farmer communities were not informed of the upcoming schedule of agricultural extension, which was usually conveyed through these communities.

Based on the effect mentioned above, agricultural extension as a form of non-formal education has the potential to increase farmers' knowledge or insight to be further used as a consideration in making precise decisions regarding farming techniques. Through non-formal education, farmers can access information to help with their decision-making process in finding alternative solutions to their agricultural problems. According to Sadono (2008), non-formal education can meet the needs for practical learning more quickly because its curriculum and learning system are more flexible and adaptable to the objectives of the learners or target farmers. Non-formal education is proven effective because the curriculum combines technical/business skills (practical skills) with character development and social care (life skills).

\section{The Effects of Encouragement to adopt eco-friendly innovation to Empowerment}

Figure 1 shows a significant effect of encouragement to adopt ecologically friendly innovation on the empowerment of farmers, in particular, through support from farmer community $\left(\mathrm{X}_{5.1}\right)$, market support $\left(\mathrm{X}_{5.4}\right)$, and technological information support $\left(\mathrm{X}_{5.5}\right)$. These three measured variables showed a direct impact, with market support showing the most substantial influence (0.78), followed by technological information support (0.73) and support from the farmer community (0.62).

\section{Market Support}

Market support is described as one of the factors supporting the success of innovations in environmentally friendly lowland rice farming. It has both direct and indirect impacts on the achievement of the innovation goals. The difference in price between the products of the innovation 
(i.e., organic rice) and conventional agricultural practices plays a part in increasing the enthusiasm of farmers to apply the principles of eco-friendly rice farming.

Here, market support refers to the availability of markets, the ease of product sale from farmers to consumers, and the method of payment, which is mostly cash. Serang and Pandeglang Regencies are relatively close to the capital of Banten Province than Lebak Regency, but with good road conditions. These factors contribute to the smooth process and the length of time of transportation. Paved roads and public transportation facilities, such as minibuses and cars, are available, allowing farmers to sell their agricultural products directly to traders or rice mill renters.

Rice is easily marketed because traders, distributors (intermediaries), and rice mill owners purchase it directly from farmers. The positive attitude of farmers towards the market support was evident from the statement of the respondents, confirming the ease of marketing, many buyers, and available information on the market. Most farmers in the study area sold their agricultural products directly to rice mill renters and traders who came to their houses. Access to the market enables farmers to improve their agricultural practices, create favorable and profitable trade, expand the distribution of farm product sales, and increase their trust in their farming business (Ahuja, 2011).

\section{Technological Information Support}

To make accurate decisions in proper crop cultivation and farm management, farmers require technological information support (E. Oos M Anwas et al., 2010). The information comprises technological innovations and market information, which in this study concern on implementing the principles of eco-friendly lowland rice farming. This section reviews it from the source of information, the ease of access to it, conformity to farming needs, and farmers' trust in the source of information.

In carrying out farming activities, farmers obtained information from agricultural extension workers/officers, fellow farmers, formulators, and traders. Some farmers had access to electronic and print media even though they were still in a low position. The dissemination of agricultural technology information through printed media (e.g., farming magazines, Sinartani newspapers, brochures, and technical guidelines) and electronic media (e.g., radio, television, and internet) increasingly follows the development of science and technology. These media potentially offer extension workers and farmers sources of agricultural information, but their availability does not guarantee that the obtained details will be disseminated or applied. In this study, the most important and easily accessed sources were agricultural extension workers, fellow farmers, and traders/formulators. This finding is in line with Tamba \& Sarma (2007), which suggests that the primary source of information is generally fellow farmers and the head of farmer communities or joint farmer communities (i.e., Gapoktan). Fatchiya (2010) affirms that information from researchers, extension workers, and mass media (i.e., internet, TV, radio, farmers' magazines/newspapers) is more difficult to obtain compared with information from other farmers, the head of farmer communities, and sellers of agricultural inputs (Ahuja, 2011). The same case applies to the study area in which access to electronic media was limited in quantity due to relatively low farmers' capacity. Some farmers who could use the internet explained that the obtained technological information met their agricultural needs and was reliable (Mulyaningsih et al., 2018; Sadono \& Jalieli, 2015).

Moreover, agricultural information disseminated through mass media, such as magazines, newspapers, radio, and television, is relatively expensive and unavailable. Examples include Sinartani newspapers and Trubus, an agricultural magazine (Iryana, 2018; Musdalipah, 2018). Despite the high demand for these media, they are difficult to obtain. At the same time, farmers culturally have low interest in reading; reading is not considered as a necessity. Farmers could read Sinartani newspapers whenever they visited the Agricultural Extension Office (BPP) (Aminah et al., 2015; Ajala et al., 2013). However, these newspapers were usually out of date (a few months or even a year ago). The distribution of reading material was somewhat challenging, primarily when the Agricultural Extension Office was located far from the farmers' villages. For this reason, universities, agricultural research institutes, NGOs, and government agencies must proactively provide information services via the internet, which is relatively inexpensive and affordable for these information providers. These results 
correspond to Ariani (2014), which affirms that providing information according to the indicators of farmers' empowerment can affect their capacity to develop vegetable farming, in particular, the ability to plan, implement, evaluate, and overcome related problems. Sources of information, such as mass media, play a very crucial role in the introduction of innovation to a community (Ruhimat, 2014).

\section{Support from Farmer Communities}

Support from the farmer community is any encouragement offered to apply the principles of environmentally friendly lowland rice farming. It is a form of active and passive participation in various activities that are organized to introduce this farming practice. Farmer communities were generally active at certain times, e.g., during field schools in the SL-PTT and SL-PHT program, technology implementation, and the utilization of biological agents (Sadono \& Jalieli, 2015; Sangaji et al., 2011). During the preparation and application, the intensity of meetings usually increased and involved cooperative activities. According to most rice farmers, encouragement from farmer communities was categorically essential specifically because it provided media for learning/exchanging experiences, accumulating farming capitals, and accessing government assistance programs.

As a place of learning, a farmer community is subjected to facilitation and training to improve the empowerment of its members through various mentoring activities (field schools) and counseling or assistance (Jaya et al., 2017). The members can feel the benefit from this learning media because they receive sufficient information on farming from the head and committee of the farmer community and agricultural extension officers.

The farmer communities in the three regencies still not optimally played their role and function as a farming organization that aimed to develop agricultural business, improve farming innovation, and accumulate/distribute necessary capital (Sriati et al., 2017; Suwarto \& Anantanyu, 2012). In general, farmer communities are expected to be able to provide input to farming systems (e.g., fertilizer), capital (e.g., savings and loans), irrigation water supply (in cooperation with a water user association, P3A), and information (counseling or extension). Besides, farmer communities are a forum for information dissemination or a means of learning for their members, i.e., facilitating demonstration activities (demonstration plot) of eco-friendly innovation (Agboola et al., 2015; Setiyawan, 2013).

Farmer communities in Serang, Pandeglang, and Lebak were categorized as supporting the adoption of environmentally friendly innovations. They actively mobilized their members to make use of these groups as media for learning/sharing experiences and create access to assistance given by the government and private parties. Such active participation was apparent from the willingness of farmers to attend agricultural extension activities.

The committee of farmer communities is tasked with empowering the members by improving their capacity, as well as encouraging them to enthusiastically follow the current developments, such as the use of new high-yielding varieties with high quality and production and the use of agricultural machinery. Las et al. (2006) claims that the existence of farmer communities in the future will be increasingly vital if it can carry out its functions effectively, namely (1) as a media of collaboration between members or with other farmer communities in facing challenges, threats, obstacles, and disturbances, especially in building favorable bargaining positions and the values of farmers in agribusiness, (2) as a media of education in which farmers can improve their competence in increasing production, income, and welfare, and (3) as a media of joint business development to achieve an efficient and productive farming scale so as to realize optimal quality, quantity, and continuity.

In this study, this observed variable was measured from the action of the head and committee of farmer communities in encouraging and mobilizing their members and the ability of these communities to establish partnerships with other parties, perform their functions as a media of learning, and provide assistance in the marketing process, infrastructure, capital, information, and access to assistance programs. In addition, lowland rice farmers in the three districts have the characteristics of having strong self-confidence in planning their farming, developing farming, and 
solving farming problems together with extension workers. In addition, farmers in the three districts have a hard-working spirit in managing their lowland rice farming.

\section{CONCLUSIONS}

Two aspects have been identified as the most influential factors on farmers' capacity to implement environmentally friendly lowland rice cultivation. First, the individual characteristics are composed of cosmopolitanism (0.93) as the strongest determinant, followed by formal education (0.78) and nonformal education (0.59). Second, the existence of encouragement to adopt environmentally-friendly innovation is mostly affected by market support (0.78), then technological information support (0.73), and support from farmer communities (0.62).

\section{ACKNOWLEDGMENTS}

The results showed that the empowerment of lowland rice farmers to adopt eco-friendly innovation was determined by individual characteristics (i.e., non-formal and formal educational attainment and cosmopolitanism) and the existence of encouragement to implement the innovation (i.e., support from farmer community, market support, and technological information support). This research is financially supported by the IsDB Research Grant Program, Sultan Ageng Tirtayasa University in 2019 (Contract No. B / 60 / UN 43.9 / PT.01.03 / 2019) of the Islamic Development Bank. We want to express our thanks to Indonesia Center of Excellence for Food Security Sultan Ageng Tirtayasa University, Indonesia.

\section{REFERENCES}

Agboola, A. F., Adekunle, I. A., \& Ogunjimi, S. I. (2015). Assessment of youth participation in indigenous farm practices of vegetable production in Oyo State, Nigeria. Journal of Agricultural Extension and Rural Development, 7(3), 73-79. https://doi.org/10.5897/jaerd2014.0590.

Ajala, A.O., Ogunjimi, S.I., Farinde, A.J. (2013). Assessment of Extension Service Delivery on Improved Cassava Technologies Among Cassava Farmers in Osun State, Nigeria. International Journal of Applied Agriculture and Apiculture Research, 9(1-2), 71-80.

Anwas, O. M., Sumardjo, Asngari, P. S., \& Tjitropranoto, P. (2010). Model of Competency Development Based on Media Utilization of Extension Worker. Jurnal Penyuluhan, 6(1), 1-10.

Ahuja, V. (2011). Cyber Extension: a Convergence of ICT and Agricultural Development. Global Media Journal, 2(2), 1-8.

Aminah, S., Sumardjo, Lubis, D. P., \& Susanto, D. (2015). Factors affecting peasants' empowerment in West Halmahera District - A case study from Indonesia. Journal of Agriculture and Rural Development in the Tropics and Subtropics, 116(1), 11-25.

Ariani, M. (2014). Analisis Konsumsi Pangan Tingkat Masyarakat Mendukung Pencapaian Diversifikasi Pangan. Gizi Indonesia, 33(1), 20-28. https://doi.org/10.36457/gizindo.v33i1.84

Astuti, M. (2012). Pemberdayaan Perempuan Miskin Berbasis Pemanfaatan Sumberdaya Lokal Melalui Pendekatan Sosial Enterpreneurship (Studi Kasus di Daerah Tertinggal, Kabupaten Pasaman, Sumatera Barat). Jurnal Sosiokonsepsia, 17(03), 241-251.

Fatchiya, A. (2010). Tingkat Kapasitas Pembudidaya Ikan dalam Mengelola Usaha Akuakultur secara Berkelanjutan Fish Farmer Capacity to Manage of Aquabusiness Sustainability. Jurnal Penyuluhan, 6(1), 74-83. http://jai.ipb.ac.id/index.php/jupe/article/viewFile/10667/8240

Herawati, H., Hubeis, A. V., Amanah, S., \& Fatchiya, A. (2018). Kapasitas Petani Padi Sawah Irigasi Teknis Dalam Menerapkan Prinsip Pertanian Ramah Lingkungan Di Sulawesi Tengah. Jurnal Pengkajian Dan Pengembangan Teknologi Pertanian, 20(2), 155. https://doi.org/10.21082/jpptp.v20n2.2017.p155-170

Iryana, A. B. (2018). Pemberdayaan Masyarakat Petani Dalam Meningkatkan Kesejahteraan Hidup Di Kecamatan Compreng Kabupaten Subang. Jurnal Academia Praja, 1(02), 125-140. https://doi.org/10.36859/jap.v1i02.69 
Jaya, M. N., Sarwoprasodjo, S., Hubeis, M., \& Sugihen, B. G. (2017). Tingkat Keberdayaan Kelompok Tani pada Pengelolaan Usahatani Padi di Daerah Istimewa Yogyakarta, Jawa Tengah. Jurnal Penyuluhan, 13(2), 166. https://doi.org/10.25015/penyuluhan.v13i2.15903

Las, I., Subagyono, K., Setiyanto, A. P., Besar, B., Dan, P., Sumberdaya, P., \& Pertanian, L. (2006). Isu Dan Pengelolaan Lingkungan Dalam Revitalisasi Pertanian Environmental Issues and Management in Agricultural Revitalization. Jurnal Penelitian Dan Pengembangan Pertanian, 25(3).

Mulyaningsih, A., \& Sumantri, A. T. (2019). Empowerment of farmers in increasing production of environmentally friendly soybean plants: Case study in Pandeglang regency Indonesia. IOP Conference Series: Earth and Environmental Science, 383(1). https://doi.org/10.1088/1755$1315 / 383 / 1 / 012010$

Mulyaningsih, A., Hubeis, A. V. S., \& Sadono, D. (2018). Partisipasi petani pada usahatani padi, jagung, dan kedelai perspektif gender. Jurnal Penyuluhan, 14(1), 145-158. https://doi.org/10.25015/penyuluhan.v14i1.18546

Musdalipah, M. (2018). Pemberdayaan Masyarakat Tentang Swamedikasi Melalui Edukasi Gema Cermat Dengan Metode Cbia. Dinamisia : Jurnal Pengabdian Kepada Masyarakat, 2(1), 106112. https://doi.org/10.31849/dinamisia.v2i1.1085

Pertiwi, P. R., Farida, I., Novianti R. (2011). Karakteristik Adopter pada Masyarakat Nelayan Kampung Cipatuguran Pelabuhan Ratu dalam Penerimaan Teknologi Baru. Jurnal Penyuluhan, 7(1), 1-9.

Pirngadi, K. (2009). Peran Bahan Organik Dalam Peningkatan Produksi Padi Berkelanjutan Mendukung Ketahan Pangan Nasional. Pengembangan Inovasi Pertanian, 2(1), 48-64. http://203.176.181.70/publikasi/ip021094.pdf

Ruhimat, I. S. (2014). Faktor-Faktor Untuk Peningkatan Kemandirian Petani Dalam Pengelolaan Hutan Rakyat: Studi Kasus Di Desa Ranggang, Kabupaten Tanah Laut, Kalimantan Selatan ( Factors Improving Self-reliance of Farmers in Community Forest Management : Case Study in Rangga. Jurnal Penelitian Sosial Dan Ekonomi Kehutanan, 11(3), 237-249.

Sadono, D. (2008). Pemberdayaan Petani: Paradigma Baru Penyuluhan Pertanian di Indonesia. Jurnal Penyuluhan, 4(1). https://doi.org/10.25015/penyuluhan.v4i1.2170

Sadono, D., \& Jalieli, A. (2015). The Level of Participation and Empowerment of Farmers Graduated SL-PTT Program in Gegesik Wetan, Cirebon District. Jurnal Penyuluhan, 9(2).

Setiyawan. (2013). Evaluasi Penerapan Teknologi pada Program Sekolah Lapang Pengelolaan Tanaman Terpadu) Padi di Kecamatan Benua Kayong Kabupaten Ketapang. Journal of Chemical Information and Modeling, 53(9), 1689-1699.

Sriati, S., Hakim, N., \& Arbi, M. (2017). Partisipasi Petani dan Efektivitas Gapoktan dalam Penguatan Lembaga Distribusi Pangan Masyarakat (LDPM) di Kecamatan Makarti Jaya Kabupaten Banyuasin. Jurnal Penyuluhan, 13(1), 88. https://doi.org/10.25015/penyuluhan.v13i1.14206

Suwarto, \& Anantanyu, S. (2012). Model Partisipasi Petani Lahan Kering. Jurnal Ekonomi Pembangunan, 13(2004), 218-234.

Tamba, M., \& Sarma, M. (2007). Faktor-Faktor Yang Mempengaruhi Kebutuhan Informasi Pertanian Bagi Petani Sayuran Di Provinsi Jawa Barat. Jurnal Penyuluhan, 3(1). https://doi.org/10.25015/penyuluhan.v3i1.2148 